\title{
ESTIMASI BIAYA PRODUKSI DALAM MERENCANAKAN LABA PADA PABRIK KARET PT. BUKIT ANGKASA MAKMUR KABUPATEN BENGKULU UTARA
}

\author{
Redy Badrudin 1) \\ Sri Sugiarti 1) \\ Friska Oktora Marbun 2) \\ 1) Staf Pengajar Jurusan SOSEK Fak.Pertanian UNIB \\ 2) Alumni Jurusan SOSEK Fak.Pertanian UNIB
}

\begin{abstract}
The aim of the factory is to get the profit. Large or small the advantage the profit that the factory can reached out, that's provide the management ability/succesfull in manage their company. Into arrange the profit planning could done by analyzing Break Event Point (BEP) and the varian analysis to estimate the product cost, checking cost, and measurement of the factory performance.The purpose of this research is (1) To know is it the process of crumb rubber on Bukit Angkasa Makmur factory Ltd has reached the level of minimum sale? (2) To know how much the value number of margin contribution, and the ratio of margin contribution, (3) To know is it in production activity (production process) on PT. Bukit Angkasa Makmur get the favourable or unfavourable varian?, (4) To know the value number of fixed cost and variable cost on PT. Bukit Angkasa Makmur.The result of this research show that the PT. Bukit Angkasa Makmur has reached the minimum level of sale with Break Event Point value (in Rp) $R p$ 201.585.596.402,50 and 21.894.818,77 Kg. The value of margin contribution is $R p$ 8.339.796.662,00, and the ratio margin of contribution value is 0.04 . The fixed cost on PT. Bukit Angksa Makmur in year of 2005 is $R p$ 8.063.423.856,10 with the variable cost $R p$ 221.881.029.070,92. The means of raw materials varian is $R p(36.507 .552 .431,99)$ favourable. The means of the direct employees is $R p(49.296,00)$ favourable. The means of overhead variable is $R p(175.905 .700,76)$ favourable. The means of fixed averhead varian is $R p(118.626 .927,28)$ favourable.
\end{abstract}

Key word : Profit, Unfavourable, Favourable

\section{PENDAHULUAN}

Pembangunan pertanian bagi bangsa Indonesia merupakan bagian dari pembangunan nasional. Oleh karena itu, untuk mendukung pembangunan pertanian diperlukan perusahaaan yang mempunyai berbagai tujuan, seperti memperluas penganekaragaman hasil pertanian guna memenuhi kebutuhan pangan, meningkatkan hasil dan mutu produksi, meningkatkan pendapatan dan taraf hidup petani disekitarnya, membuka lapangan kerja, dan meningkatkan eksport, serta mendukung pembangunan daerah. Data tahun 2002 menunjukkan bahwa sektor pertanian mampu menyerap kurang lebih 59,50 persen dari seluruh angkatan kerja di Indonesia dengan sumbangan 49,38 persen terhadap Produk Domestik Regional Bruto. Khususnya untuk Propinsi Bengkulu pada tahun 2003 sektor pertanian menyerap 78,03 persen dari angkatan kerja yang 
ada, dengan kontribusi terhadap Produk Domestik Regional Bruto sebesar 75,29 persen, mengalami kenaikan dibandingkan tahun 2002 yang menyerap 75,29 persen dari angkatan kerja yang ada dengan kontribusi terhadap Produk Domestik Bruto 50,48 persen (BPS Bengkulu, 2003).

Kontribusi subsektor perkebunan dalam Produk Domestik Regional Bruto Bengkulu semakin meningkat. Pada awal Repelita VI kontribusi subsektor perkebunan baru mencapai 6,45 persen, tetapi pada tahun 2003 kontribusinya telah meningkat menjadi 11,28 persen. Peningkatan ini mengindikasikan bahwa andil subsektor perkebunan dalam perekomoian Propinsi Bengkulu semakin penting (BPS Bengkulu, 2003).Usaha perkebunan di Propinsi Bengkulu dilakukan oleh rumah tangga perkebunan rakyat dan perkebunan besar swasta. Rumah tangga yang mengusahakan tanaman perkebunan di Propinsi Bengkulu dari tahun ke tahun terus mengalami peningkatan. Pada tahun 2002 rumah tangga yang mengusahakan perkebunan rakyat di daerah ini diperkirakan mencapai 307.403 rumah tangga sedangkan pada tahun 2003 jumlahnya diperkirakan telah mencapai 360.321 rumah tangga. Sementara itu, perusahaan besar swasta yang bergerak aktif di sektor perkebunan jumlahnya masih kurang dari 10 perusahaan (BPS Bengkulu, 2003).Tanaman perkebunan yang sangat potensial untuk dikembangkan dan diminati investor dari luar Propinsi Bengkulu adalah tanaman karet dan kelapa sawit. Sebab, selain memiliki nilai ekonomis yang tinggi, lahan yang tersedia cocok untuk pengembangan tanaman perkebunan karet masih cukup luas. Pada tahun 2003 total luas lahan tanaman karet seluas 96,18 ribu hektar (BPS Bengkulu, 2003).Letak geografis Bengkulu berada diantara 20-50 Lintang Selatan dan garis 1010-1040 Bujur Timur yakni dengan luas wilayah 1.837.074 Ha, tersebar di setiap daerah tingkat II masing-masing di Kabupaten Bengkulu Selatan 29,5 persen. Kabupaten Bengkulu Utara 52,4 persen, Kabupaten rejang Lebong 18,0 persen dan Kota Bengkulu 0,1 persen. Ini menunjukkan bahwa Propinsi Bengkulu sangat potensial untuk pengembang subsektor perkebunan (BPS Bengkulu, 2003).Salah satu komoditas perkebunan yang mempunyai peran yang cukup strategis dalam perekonomian Indonesia adalah karet. Karet merupakan bahan baku utama pembuatan ban dan bahan tekstil serta merupakan salah satu komoditas eksport non migas.

Perkebunan karet di Bengkulu dalam perkembangannya tidak hanya diusahakan oleh rumah tangga atau perkebunan rakyat, akan tetapi diusahakan juga oleh perusahaanperusahaan. Tujuan perusahaan pada umumnya adalah untuk memperoleh laba, dan besar 
kecilnya laba yang dapat dicapai merupakan ukuran kesuksesan manajemen dalam mengelola perusahaannya. Oleh karena itu, perusahaan harus mampu memperkirakan biaya produksi dalam merencanakan laba agar dapat menjadi perusahaan yang berhasil.Menyusun perencanaan laba perusahaan dapat dilakukan dengan berbagai cara, antara lain dengan program budget. Sebagian besar dari program budget berisi taksiran penghasilan yang akan diperoleh dan biaya-biaya yang akan terjadi. Penggunaan budget ini akan lebih bermanfaat bagi manajemen perusahaan apabila disertai dengan analisa perencanaan laba misalnya dengan analisis Titik Impas.Titik impas merupakan suatu kondisi perusahaan yang penghasilan dari penjualannya hanya cukup menutupi biaya yang dikeluarkan. Titik impas mampu memberikan informasi kepada pimpinan perusahaan mengenai berbagai tingkat volume penjualan serta hubungannya dengan kemungkinan kemampuan memperoleh laba.

Selain perhitungan perencanaan laba juga diperlukan analisis varian dalam membandingkan antara biaya stndar dengan biaya sesungguhnya sehingga akan menghasilkan varian menguntungkan atau varian merugikan. Penentuan varian ini sangat besar manfaatnya bagi perusahaan, antara lain untuk pengendalian biaya dan mengestimasi biaya produksi serta mengukur kinerja perusahaan. Pengendalian biaya harus didahului dengan penentuan biaya yang seharusnya dikeluarkan untuk memproduksi satu satuan produk. Jika biaya yang seharusnya ini telah ditetapkan, akuntansi bertugas untuk memantau apakah pengeluaran biaya yang sesungguhnya sesuai dengan standar. Sehubungan dengan ini ada tiga jenis biaya yang perlu dikendalikan yaitu biaya bahan baku, biaya tenaga kerja langsung (TKL) dan biaya overhead pabrik (BOP). Informasi mengenai selisih antara biaya standar dengan biaya yang sesungguhnya, yang tujuan pokoknya untuk pengendalian biaya yang dikeluarkan perusahaan berguna bagi manajemen untuk dipakai sebagai dasar estimasi biaya produksi selanjutnya dan untuk menentukan keuntungan serta menilai prestasi pimpinan perusahaan dalam mengelola biaya perusahaan. Berdasarkan uraian diatas maka penulis tertarik membahas suatu permasalahan dalam bentuk skripi dengan diberi judul "Kajian Break Even Point dan Analisis Varinace Biaya Produksi Pada Pabrik Karet PT. Bukit Angkasa Makmur (PT.BAM) Kecamatan Talang Empat Kabupaten Bengkulu Utara. 


\section{METODOLOGI PENELITIAN}

Lokasi penelitian ditentukan dengan sengaja (purposive), yaitu di Perusahaan PT. Bukit Angkasa Makmur Kecamatan Talang Empat Kabupaten Bengkulu Utara. Dengan pertimbangan bahwa perusahaan tersebut harus melakukan pengolahan karet yang telah lama beroperasi dan telah berkembang dengan baik. Penelitian ini digunakan data time series, yaitu data yang diperoleh dari suatu fenomena tertentu yang didapat dari beberapa interval waktu tertentu. Data yang digunakan untuk analisa titk impas yaitu data tahun 2005. Sedangkan data untuk analisis pengendalian biaya produksi menggunakan data 5 tahun, sehingga nantinya didapat gambaran yang jelas mengenai masalah yang diteliti.

Penelitian ini menggunakan nilai titik impas pada PT. BAM dapat digunakan rumus yang merupakan perbadingan antara total biaya tetap terhadap rasio marjin kontribusi . Disamping itu juga menggunakan analisis varian untuk mengethaui sistem pengendalian biaya bahan baku,harga, tenaga kerja, dan overhead. Dengan kriteria keputusan sebagai berikut Apabila : Apabila : Harga atau penggunaan masukan aktual > harga atau penggunaan standar tidak mengguntungkan (Unfavourable) dan harga atau penggunaan masukan aktual < harga atau penggunaan standar mengguntungkan. Jika Total Varian $(+)$ maka varian menguntungkan (Unfavourable) dan Jika Total varian (-) maka varian tidak menguntungkan (Favourable).

\section{HASIL DAN PEMBAHASAN}

\section{Struktur Biaya}

Biaya tetap yaitu biaya jumlah totalnya tidak terpengaruh oleh volume produksi. Biaya yang tergolong biaya tetap dikeluarkan oleh PT. BAM adalah biaya tenaga kerja, biaya penyusutan, biaya pajak, biaya asuransi, biaya keamanan, serta biaya entertainment (Biaya lainlain). Sedangkan biaya tetap berasal dari biaya semi variabel yaitu biaya pemeliharaan dan perawatan, biaya administrasi dan umum, biaya listrik dan biaya telepon. Beban biaya terbesar dibandingkan dari seluruh bagian biaya tetap adalah biaya tenaga kerja dengan nilai sebesar Rp 5.765.197.346,-. Beban biaya tetap berikutnya berupa pajak sebesar Rp 312.379.648,-,-. Biaya pajak yang dikeluarkan oleh perusahaan untuk membayar pajak Bumi dan Bnagunan sebesar Rp 42.910.816,-, untuk PPN Pasal 25 sebesar Rp 265.347.801,- dan untuk PPN Pasal 22 sebesar Rp 4.121.031.

Beban biaya tetap berikutnya berupa biaya penyusutan sebesar Rp 733.669.918,-. Dari nilai penyusutan pada lampiran 3 dapat dilihat bahwa nilai yang terbesar adalah nilai penyusutan 
mesin dan perlengkapan sebesar Rp 500.557.213,-- sedangkan nilai penyusutan yang terendah adalah nilai penyusutan instalasi telepon sebesar $\mathrm{Rp} 1.757 .561$. Pengeluaran biaya tetap yang paling kecil adalah biaya entertainment sebesar rp 181.840.004,-- Dan biaya tetap berikutnya adalah biaya asuransi sebesar Rp 55.456.873,-. Biaya asuransi ini dikeluarkan oleh perusahaan untuk pembayaran Astek dan Jamsostek. Asuransi ini dilakukan perusahaan tidak lain agar nantinya apabila terjadi sesuatu diluar keinginan (kecelakaan), paling tidak masih ada biaya untuk tambahan sebagai ganti rugi.

Tabel 1. Biaya Tetap Pada PT. Bukit Angkasa Makmur Tahun 2005

\begin{tabular}{ll}
\hline \multicolumn{1}{c}{ Jenis Biaya } & \multicolumn{1}{c}{ Nilai (Rp) } \\
\hline Biaya tenaga kerja & $5.765 .197 .346,00$ \\
Biaya Penyusutan & $733.669 .918,00$ \\
Pajak & $312.379 .648,00$ \\
Biaya asuransi & $55.456 .873,00$ \\
Entertainment & $181.840 .004,00$ \\
Biaya Keamanan & $10.000 .000,00$ \\
Biaya tetap dari biaya semi variabel & \\
- Biaya Pemeliharaan dan Perawatan & $419.602 .386,50$ \\
- Biaya Administrasi dan Umum & $248.653 .033,00$ \\
- Listrik & $313.581 .954,80$ \\
- Telepon & $23.042 .692,80$ \\
\hline Jumlah Biaya Tetap & $8.063 .423 .856,10$ \\
\hline Sumber : Hasil Olahan Data Sekunder Tahun 2006
\end{tabular}

Biaya tetap selanjutnya adalah biaya keamanan dan entertainment. Pengeluaran biaya keamanan sebasar Rp 10.000.000,-, digunakan untuk dana aparat dari kepolisian, seperti gaji, biaya makan dan minum, uang rokok, dan lain-lain. Sedangkan biaya entertainment yang dikeluarkan oleh perusahaan sebesar $\operatorname{Rp} 181.840 .004,-$, berupa biaya yang tidak terduga diluar hubungan dengan produksi crumb rubber. Biaya yang termasuk entertainment misalnya dana sosial yang berupa dana iuran dan sumbangan, dana untuk kunjungan tamu dan dana untuk karyawan yang pergi menjadi utusan pihak perusahaan atau yang mewakili perusahaan untuk mendatangi undangan dan perlombaan. Untuk lebih rincinya dapat dilihat pada tabel 1 diatas. Biaya tetap yang berasal dari biaya semi variabel yaitu biaya pemeliharaan dan perawatan, biaya administrasi dan umum, biaya listrik dan biaya telepon. Biaya ini dipisahkan dengan menggunakan metode kuadrat terkecil dan metode penelususran langsung. Untuk pemeliharaan dan perawatan dipisahkan dengan menggunakan metode kuadrat terkecil. Sedangkan untuk biaya administrasi dan umum, listrik dan telepon dipisahkan dengan menggunakan metode penelusuran langsung. Untuk biaya administrasi dan umum dipisahkan dengan melihat jenis 
biaya yang dikeluarkan. Sedangkan biaya listrik dipisahkan dengan melihat biaya pemakaian, biaya beban, dan biaya lampu jalan. Sedangkan untuk biaya telepon pemisahan biaya dilihat dari biaya pemakaian pulsa, biaya bulanan dan PPN 10\% (UU No. 18 Tahun 2000).

Biaya variabel adalah biaya yang jumlah totalnya berubah sebanding dengan perubahan volume produksi. Biaya yang tergolong biaya variabel adalah biaya bahan baku, biaya bahan penolong, pengangkutan dalam pabrik, biaya pengolahan limbah. Sedangkan biaya variabel yang berasal dari biaya semi variabel sama dengan biaya semi variabel pada biaya tetap.Komponen biaya variabel yang paling besar proporsinya adalah biaya bahan baku dengan nilai Rp 215.057.125.789,-, ini disebabkan besarnya biaya dalam pembelian bahan baku agar dapat memenuhi pesanan buyer. Biaya variabel selanjutnya adalah biaya bahan penolong, berupa bahan kimia yang berguna untuk meningkatkan elastisitas, untuk mengurangi kadar air pada remah karet. Biaya bahan penolong yang dikeluarkan oleh perusahaan sebesar Rp 280.471.000,-

Tabel 2. Biaya Variabel Pada PT. Bukit Angkasa Makmur Tahun 2005

\begin{tabular}{lr}
\hline \multicolumn{1}{c}{ Jenis Biaya } & Nilai (Rp) \\
\hline Bahan baku & $150.038 .489 .115,00$ \\
Bahan penolong & $280.471 .000,00$ \\
Pengangkutan dalam pabrik & $50.148 .752,00$ \\
Biaya pengolahan limbah & $55.166 .826,00$ \\
Biaya Penjualan & $5.789 .345 .333,00$ \\
Biaya variabel dari biaya semi variabel & \\
- Biaya pemeliharaan dan perawatan & $3.447 .669,52$ \\
- Biaya adminitrasi dan umum & $140.386 .730,00$ \\
- Listrik & $470.372 .932,20$ \\
- Telepon & $34.564 .039,20$ \\
\hline Jumlah Biaya variabel & $221.881 .029 .070,92$ \\
\hline Sumber : Hasil Olahan Data Sekunder Tahun 2006
\end{tabular}

Berdasarkan Tabel 2, juga dapat dilihat bahwa untuk pengeluaran biaya pengangkutan dalam pabrik sebesar Rp 50.148.752,-. Selanjutnya untuk pengeluaran biaya pengolahan limbah sebesar Rp 55.166.826,-- Beban biaya variabel dari biaya semi variabel berupa biaya pemeliharaan dan perawatan sebesar Rp 3.447.669,52, seterusnya pengeluaran untuk biaya administrasi dan umum sebesar Rp 140.386.730,-- Sedangkan untuk biaya listrik sebesar Rp 470.372.932,- dan untuk biaya telepon sebesar Rp 34.564.039,20.3.2. Total biaya merupakan hasil penjumlahan antara biaya tetap dan biaya variabel. Total biaya yang meliputi keseluruhan 
biaya yang dikeluarkan usaha pengolahan crumb rubber PT. Bukit Angkasa Makmur pada tahun 2005. Hal ini dapat dilihat pada Tabel 3.

Tabel 3. Total Biaya Usaha Crumb Rubber PT. BAM Tahun 2005

\begin{tabular}{lr}
\hline \multicolumn{1}{c}{ Jenis Biaya } & Nilai (Rp) \\
\hline Biaya Tetap & $8.063 .423 .856,10$ \\
Biaya Variabel & $221.881 .029 .070,92$ \\
\hline Jumlah & $229.944 .452 .937,02$ \\
\hline
\end{tabular}

Sumber : Hasil Olahan Data Sekunder Tahun 2006

\section{Titik Impas}

Perhitungan titik impas pada pabrik karet PT. BAM untuk penjualan Crumb Rubber selama tahun 2005 dapat dilihat pada Tabel 4. Titik impas merupakan suatu cara yang digunakan pimpinan perusahaan untuk mengetahui atau untuk merencanakan pada volume produksi atau volume penjualan berapakah perusahaan yang bersangkutan tidak memperoleh keuntungan dan tidak menderita kerugian. Diketahuinya impas maka dapat direncanakan tingkat volume produksi atau volume penjualan yang akan mendatangkan keuntungan bagi perusahaan.

Tabel 4. Nilai Titik Impas Pada PT. Bukit Angkasa Makmur Tahun 2005

\begin{tabular}{|c|c|}
\hline Uraian & Nilai \\
\hline Volume Penjualan (Kg) & 22.644 .720 \\
\hline Nilai Penjualan (Rp) & $230.220 .825 .692,00$ \\
\hline Biaya Tetap (Rp) & 8.063.423.856,10 \\
\hline Biaya Variabel (Rp) & $221.881 .029 .070,92$ \\
\hline Titik Impas (Unit) & $21.894 .818,77$ \\
\hline Titik Impas (Rp) & $201.585 .596 .402,50$ \\
\hline
\end{tabular}

Sumber : Hasil lahan Data Sekunder Tahun 2006

Pada Tabel 4 dapat dilihat bahwa nilai titik impas (dalam rupiah) pada produksi karet PT. BAM sebesar $\operatorname{Rp} 201.585 .596 .402,50$ atau dalam unit/satuan penjualan sebanyak $21.894 .818,77 \mathrm{Kg}$. Artinya bahwa perusahaan karet pada PT. BAM harus melakukan Penjualan sebanyak 21.894.818,77 kg dengan nilai penjualan sebesar Rp 201.585.596.402,52, supaya tidak mengalami kerugian maupun keuntungan dengan kata lain hanya cukup untuk menutupi biaya produksi.

\section{Analisis Marjin Kontribusi dan Rasio Marjin Kontribusi}

Marjin kontribusi merupakan jumlah yang tersisa dari penjualan setelah dikurangi biaya variabel. Jumlah ini kemudian akan digunakan untuk menutupi biaya tetap pada periode tersebut.Berdasarkan hasil perhitungan nilai marjin kontribusi crumb rubber (lampiran 5) 
diketahui nilai marjin kontribusi PT. BAM dalam produksi crumb rubber adalah sebesar Rp $368.28 \mathrm{Kg}$ atau sebesar Rp 8.339.796.622 .untuk total produksi tahun 2005. Nilai marjin kontribusi yang diperoleh ini lebih besar dibanding dengan biaya tetap yang dikeluarkan oleh PT. BAM dalam memproduksi crumb rubber. Hal ini berarti bahwa PT. BAM memperoleh keuntungan atau laba dari kegiatan produksi crumb rubber yang dilaksanakannya.Pada lampiran 5 terlihat bahwa nilai rasio marjin kontribusi PT. BAM adalah sebesar 0,04 atau senilai $4 \%$. Hal ini berarti bahwa perubahan penjualan sebesar $1 \%$ akan menyebabkan perubahan kontribusi penjualan terhadap biaya tetap sebesar $4 \%$.

\section{Analisis Varian Biaya Produksi}

Analisis varian adalah analisis perbedaan yang timbul karena hasil aktualnya tidak sama dengan standar. Analisis varian sangat penting utnuk mengetahui penyimpangan yang terjadi dan untuk menetapkan kebijakan penanggulangan yang mungkin dapat dilakukan untuk pembebanan pertanggungjawaban.Untuk dapat mengetahui adanya penyimpangan biaya atau tidak, perlu dianalisis varian bahan baku, varian tenaga kerja langsung dan varian BOP yang terdiri dari Varian BOP tetap dan varian BOP variabel

\section{Varian Biaya Bahan Baku}

Varian biaya bahan baku adalah perbedaan dari varian harga aktual dengan varian harga standar. Varian timbul karena perusahaan telah membeli bahan baku lebih tinggi atau lebih rendah dibanding harga standar. Berdasarkan hasil perhitungan pada Tabel 5 dapat dilihat varian biaya bahan baku dari tahun 1996-2005.

Tabel 5. Varian Harga Bahan Baku Tahun 1996-2005

\begin{tabular}{cccc}
\hline Tahun & Biaya Aktual & Biaya Standar & Varian (Rp) \\
\hline 1996 & $22.849 .828 .450,00$ & $32.188 .192 .550,75$ & $(9.338 .364 .100,75) \mathrm{F}$ \\
1997 & $15.125 .485 .000,00$ & $20.492 .912 .607,10$ & $(5.367 .427 .607,10) \mathrm{F}$ \\
1998 & $28.915 .785 .150,00$ & $34.365 .782 .046,75$ & $(5.449 .996 .896,75) \mathrm{F}$ \\
1999 & $41.413 .075 .000,00$ & $62.335 .291 .794,60$ & $(20.922 .216 .794,60) \mathrm{F}$ \\
2000 & $51.166 .707 .000,00$ & $65.539 .776 .107,68$ & $(14.373 .069 .107,68) \mathrm{F}$ \\
2001 & $60.164 .926 .000,00$ & $77.171 .745 .632,42$ & $(17.006 .819 .632,42) \mathrm{F}$ \\
2002 & $56.683 .578 .000,00$ & $88.122 .557 .701,92$ & $(31.438 .979 .701,92) \mathrm{F}$ \\
2003 & $68.250 .208 .500,00$ & $93.884 .380 .144,08$ & $(25.634 .171 .644,08) \mathrm{F}$ \\
2004 & $80.148 .264 .750,00$ & $139.528 .154 .923,47$ & $(59.379 .890 .173,47) \mathrm{F}$ \\
2005 & $96.964 .875 .000,00$ & $172.939 .163 .250,00$ & $(75.974 .288 .250,00) \mathrm{F}$ \\
\hline Total & $521.682 .732 .850,00$ & $785.567 .956 .758,77$ & $(264.885 .223 .908,77) \mathrm{F}$ \\
Rata- & $52.168 .273 .285,00$ & $78.656 .795 .675,88$ & $(26.488 .522 .390,88) \mathrm{F}$ \\
rata & & & \\
\hline Sumber & & & \\
\hline
\end{tabular}

Sumber : Hasil Olahan Data Sekunder Tahun 2006 
Berdasarkan Tabel 5, hasil perhitungan rata-rata varian biaya bahan baku senilai Rp $(8.495 .891 .419 .417,50)$ Favourable. Varian biaya bahan baku pada PT. BAM mulai tahun 19992005 mengalami varian menguntungkan (favourable). Hal ini menunjukkan bahwa bagian pembelian dalam penetapan biaya standar telah direncanakan dengan baik.

\section{Varian Penggunaan Bahan Baku}

Varian penggunaan bahan baku adalah varian yang timbul karena penggunaan bahan baku aktual yang lebih besar atau lebih kecil dibandingkan dengan penggunaan standar di dalam pengolahan produk crumb rubber. Berdasarkan Tabel 6 dapat dihitung varian penggunaan bahan baku.

Tabel 6. Biaya Bahan Baku Pada Tahun 1996-2005

\begin{tabular}{cccc}
\hline Tahun & $\begin{array}{c}\text { Penggunaan Aktual Pada } \\
\text { Harga Standar (Rp) }\end{array}$ & $\begin{array}{c}\text { Penggunaan Standar Pada } \\
\text { Harga Standar (Rp) }\end{array}$ & Varian (Rp) \\
\hline 1996 & $32.188 .192 .550,75$ & $33.646 .764 .608,25$ & $(1.458 .572 .057,50) \mathrm{F}$ \\
1997 & $20.492 .912 .607,10$ & $31.585 .715 .694,00$ & $(11.092 .803 .086,90) \mathrm{F}$ \\
1998 & $34.365 .782 .046,75$ & $38.450 .026 .037,50$ & $(4.084 .243 .990,75) \mathrm{F}$ \\
1999 & $62.335 .291 .794,60$ & $61.263 .339 .102,30$ & $1.071 .952 .692,30$ UF \\
2000 & $65.539 .776 .107,68$ & $67.958 .795 .246,72$ & $(2.419 .019 .139,04) \mathrm{F}$ \\
2001 & $77.171 .745 .632,42$ & $77.170 .976 .030,42$ & $769.602,00$ UF \\
2002 & $88.122 .557 .701,92$ & $90.681 .470 .267,68$ & $(2.558 .912 .565,76) \mathrm{F}$ \\
2003 & $93.884 .380 .144,08$ & $99.490 .544 .974,28$ & $(5.606 .164 .830,20) \mathrm{F}$ \\
2004 & $139.528 .154 .923,47$ & $179.148 .302 .556,50$ & $(39.620 .147 .633,03) \mathrm{F}$ \\
2005 & $172.939 .163 .250,00$ & $207.362 .322 .647,28$ & $(34.423 .159 .397,28) \mathrm{F}$ \\
\hline Total & $785.567 .956 .758,77$ & $886.758 .257 .164,93$ & $(100.190 .300 .406,16) \mathrm{F}$ \\
Rata-rata & $78.556 .795 .675,88$ & $88.675 .825 .716,49$ & $(10.019 .030 .040,62) \mathrm{F}$ \\
\hline Sumber:
\end{tabular}

Sumber : Hasil Olahan Data Sekunder Tahun 2006

Tabel 6 menunjukkan bahwa penggunaan biaya bahan baku pada tahun 1999 dan tahun 2001 terjadi varian yang tidak menguntungkan (Unfavourable). Penyebab dari varian unfavourable adalah terjadinya biaya penggunaan standar yang ditaksir lebih kecil dari biaya penggunan aktual. Hal ini disebabkan, penggunaan bahan baku yang ada banyak sehingga terjadi penurunan harga bahan baku.

Selain varian unfavourable, terjadi juga varian favourable, menunjukkan bahwa biaya penggunaan standar ditaksir berdasarkan pengalaman tahun sebelumnya, iklim, cuaca dan tidak terlepas dari seberapa besar kemampuan kapasitas pabrik dalam menghasilkan crumb rubber dalam 1 periode. 


\section{Varian Anggaran Bahan Baku}

Varian anggaran bahan baku adalah varian kuantitas input aktual pada harga aktual dengan kuntitas input standar pada harga standar di dalam pengolahan produk crumb rubber. Berdasarkan Tabel 7 dapat dihitung varian anggaran bahan baku. Untuk lebih jelas dapat dilihat pada Tabel 7.

Tabel 7. Varian Kuantitas Aktual Pada Harga Aktual dan Kuantitas Standar Pada Harga Standar Pada Tahun 1996-2005

\begin{tabular}{cccc}
\hline Tahun & $\begin{array}{c}\text { Kuantitas Input Aktual } \\
\text { Pada Harga Aktual (Rp) }\end{array}$ & $\begin{array}{c}\text { Kuantitas Input Standar } \\
\text { Pada Harga Standar (Rp) }\end{array}$ & Varian (Rp) \\
\hline 1996 & $22.849 .828 .450,00$ & $33.646 .764 .608,25$ & $(10.796 .936 .158,25) \mathrm{F}$ \\
1997 & $15.125 .485 .00,00$ & $31.585 .715 .694,00$ & $(16.460 .230 .694,00) \mathrm{F}$ \\
1998 & $28.915 .785 .150,00$ & $38.450 .026 .037,50$ & $(9.534 .240 .887,50) \mathrm{F}$ \\
1999 & $41.413 .075 .000,00$ & $61.263 .339 .102,30$ & $(19.850 .264 .102,30) \mathrm{F}$ \\
2000 & $51.166 .707 .000,00$ & $67.950 .795 .246,72$ & $(16.792 .088 .246,72) \mathrm{F}$ \\
2001 & $60.164 .926 .000,00$ & $77.170 .976 .030,42$ & $(17.006 .050 .030,42) \mathrm{F}$ \\
2002 & $56.683 .578 .000,00$ & $90.681 .470 .267,68$ & $(33.997 .892 .267,68) \mathrm{F}$ \\
2003 & $68.250 .208 .500,00$ & $99.490 .544 .974,28$ & $(31.240 .336 .474,28) \mathrm{F}$ \\
2004 & $80.148 .264 .750,00$ & $179.148 .302 .556,50$ & $(99.000 .037 .806,50) \mathrm{F}$ \\
2005 & $96.964 .875 .000,00$ & $207.362 .322 .647,28$ & $(110.397 .447 .647,28) \mathrm{F}$ \\
\hline Total & $521.682 .732 .850,00$ & $886.758 .257 .164,93$ & $(365.075 .524 .314,93) \mathrm{F}$ \\
Rata- & $52.168 .273 .285,00$ & $88.675 .825 .716,49$ & $(36.507 .552 .431,49) \mathrm{F}$ \\
rata & & & \\
\hline Sumber : Hasil Olahan Data Sekunder Tahun 2006 &
\end{tabular}

Tabel 7 menunjukkan bahwa kuantitas input aktual pada harga aktual dengan kuantitas input standar pada harga standar selalu terjadi varian menguntungkan (favourable), dengan nilai ratarata sebesar Rp $(36.507 .552 .431,49)$ Favourable. Penyebab selalu terjadinya varian yang menguntungkan adalah kuantitas input standar pada harga standar ditaksir berdasarkan pengalaman dan didukung oleh musim seperti musim penghujan atau kemarau, serta penentuan standar tidak terlepas dari seberapa besar kemampuan kapasitas pabrik dalam menghasilkan crumb rubber.

\section{Varian Tarif Upah Langsung}

Varian tarif upah timbul karena perusahaan telah membayar upah langsung dengan tarif lebih tinggi atau lebih rendah dibandingkan dengan tarif upah langsung standar. Jumlah total rupiah varian tarif upah langsung dapat dihitung sebesar varian tarif upah langsung perjam dikalikan jam kerja aktual. Selisih tarif upah dari tahun 1999-2005 dapat dilihat pada Tabel 8. 
Tabel 8. Varian Tarif Upah Pada Tahun 1996-2005

\begin{tabular}{cccc}
\hline Tahun & Tarif Aktual $(\mathrm{Rp})$ & Tarif Standar $(\mathrm{Rp})$ & Varian (Rp) \\
\hline 1996 & $7.437 .500,00$ & $6.247 .500,00$ & $1.190 .000,00 \mathrm{UF}$ \\
1997 & $7.853 .450,00$ & $6.294 .750,00$ & $1.558 .700,00 \mathrm{UF}$ \\
1998 & $7.968 .030,00$ & $8.087 .850,00$ & $(119.820,00) \mathrm{F}$ \\
1999 & $8.398 .600,00$ & $8.098 .650,00$ & $299.950,00 \mathrm{UF}$ \\
2000 & $8.985 .000,00$ & $8.685 .500,00$ & $299.500,00 \mathrm{UF}$ \\
2001 & $9.292 .250,00$ & $9.592 .000,00$ & $(299.750,00) \mathrm{F}$ \\
2002 & $14.987 .500,00$ & $16.696 .075,00$ & $(1.708 .575,00) \mathrm{F}$ \\
2003 & $15.287 .250,00$ & $16.696 .075,00$ & $(1.408 .825,00) \mathrm{F}$ \\
2004 & $16.202 .700,00$ & $16.712 .785,00$ & $(510.085,00) \mathrm{F}$ \\
2005 & $17.402 .900,00$ & $17.312 .885,00$ & $90.015,00 \mathrm{UF}$ \\
\hline Total & $113.815 .180,00$ & $114.424 .070,00$ & $(608.890,00) \mathrm{F}$ \\
Rata-rata & $11.381 .518,00$ & $11.442 .407,00$ & $(60.889,00) \mathrm{F}$ \\
\hline
\end{tabular}

Sumber : Hasil Olahan Data Sekunder Tahun 2006

Tabel 8 menunjukkan bahwa varian tarif upah rata-rata unfavourable dengan nilai sebesar Rp $(60.889,00)$ Favourable. Varian tarif upah favourable terjadi pada tahun 1998, 2001, 2002 , 2003 dan 2004. Sedangkan varian tarif upah unfavourable terjadi pada tahun 1996, 1997, 1999, 2000, dan 2005. Hal ini disebabkan tarif upah standar berbeda untuk pekerjaan tertentu dan adanya kenaikan jabatan yang mengakibatkan perubahan tarif upah standar.

\section{Varian Efisiensi Upah}

Jumlah varian upah langsung dalam rupiah dihitung dari selisih jam kerja langsung aktual pada tarif standar dengan jam kerja langsung standar pada tarif aktual. Berdasarkan standar upah TKL dan upah TKL aktual, maka varian efisiensi upah dapat dicari serta dapat dilihat pada Tabel 9

Tabel 9. Varian Efisiensi Upah TKL Tahun 1996-2005

\begin{tabular}{cccc}
\hline Tahun & Efisiensi Aktual (Rp) & Efisiensi Standar (Rp) & Varian (Rp) \\
\hline 1996 & $6.247 .500,00$ & $6.300 .000,00$ & $(52.500,00) \mathrm{F}$ \\
1997 & $6.294 .750,00$ & $6.300 .000,00$ & $(5.250,00) \mathrm{F}$ \\
1998 & $8.087 .850,00$ & $8.100 .000,00$ & $(12.150,00) \mathrm{F}$ \\
1999 & $8.098 .650,00$ & $8.100 .000,00$ & $(1.350,00) \mathrm{F}$ \\
2000 & $8.685 .500,00$ & $8.700 .000,00$ & $(14.500,00) \mathrm{F}$ \\
2001 & $9.592 .000,00$ & $9.600 .000,00$ & $(8.000,00) \mathrm{F}$ \\
2002 & $16.696 .075,00$ & $16.710 .000,00$ & $(13.925,00) \mathrm{F}$ \\
2003 & $16.696 .075,00$ & $16.710 .000,00$ & $(13.925,00) \mathrm{F}$ \\
2004 & $16.712 .785,00$ & $16.710 .000,00$ & $2.785,00 \mathrm{UF}$ \\
2005 & $17.312 .885,00$ & $17.310 .000,00$ & $2.885,00 \mathrm{UF}$ \\
\hline Total & $114.424 .070,00$ & $114.540 .000,00$ & $(115.930,00) \mathrm{F}$ \\
Rata- & $11.442 .407,00$ & $11.454 .000,00$ & $(11.593,00) \mathrm{F}$ \\
rata & & &
\end{tabular}


Dilihat dari nilai rata-rata menunjukkan bahwa selisih efisiensi upah TKL favourable (menguntungkan). Varian rata-rata tersebut senilai $\mathrm{Rp}(11.593,-)$ favourable, dalam arti manajemen PT. BAM telah dapat menetapkan efisiensi upah dengan efektif.

\section{Total Varian Tenaga Kerja}

Total varian tenaga kerja adalah varian jam aktual pada tarif aktual dengan jam standar pada tarif standar. Berdasarkan Tabel 10 dapat dihitung total varian tenaga kerja. Untuk lebih jelas dapat dilihat pada Tabel 10.

Tabel 10. Varian Total Tenaga Kerja

\begin{tabular}{cccc}
\hline Tahun & $\begin{array}{c}\text { Jam Aktual Pada Tarif } \\
\text { Aktual (Rp) }\end{array}$ & $\begin{array}{c}\text { Jam Standar Pada Tarif } \\
\text { Standar (Rp) }\end{array}$ & Varian (Rp) \\
\hline 1996 & $7.437 .500,00$ & $6.300 .000,00$ & $1.242 .500,00 \mathrm{UF}$ \\
1997 & $7.853 .450,00$ & $6.300 .000,00$ & $1.563 .950,00$ UF \\
1998 & $7.968 .030,00$ & $8.100 .000,00$ & $(107.670,00) \mathrm{F}$ \\
1999 & $8.398 .600,00$ & $8.100 .000,00$ & $301.300,00 \mathrm{UF}$ \\
2000 & $8.985 .000,00$ & $8.700 .000,00$ & $314.000,00 \mathrm{UF}$ \\
2001 & $9.292 .250,00$ & $9.600 .000,00$ & $(291.750,00) \mathrm{F}$ \\
2002 & $14.987 .500,00$ & $16.710 .000,00$ & $(1.694 .650,00) \mathrm{F}$ \\
2003 & $15.287 .250,00$ & $16.710 .000,00$ & $(1.394 .900,00) \mathrm{F}$ \\
2004 & $16.202 .700,00$ & $16.710 .000,00$ & $(512.870,00) \mathrm{F}$ \\
2005 & $17.402 .900,00$ & $17.310 .000,00$ & $87.130,00 \mathrm{UF}$ \\
\hline Total & $113.815 .180,00$ & $114.540 .000,00$ & $(492.960,00) \mathrm{F}$ \\
Rata-rata & $11.381 .518,00$ & $11.454 .000,00$ & $(49.296,00) \mathrm{F}$ \\
\hline
\end{tabular}

Sumber : Hasil Olahan Data Sekunder Tahun 2006

Dilihat dari Tabel 10 , Variannya menunjukkan nilai yang favourable. Artinya Pihak manajemen PT. BAM Dalam menetapkan tarif standar telah sesuai dengan keterampilan yang dimiliki tenaga kerja.

\section{Varian Biaya Overhead Pabrik}

Varian pengeluaran overhead pabrik variabel adalah varian overhead pabrik variabel aktual dengan overhead pabrik standar. Berdasarkan Tabel 11 dapat dihitung varian overhead pabrik variabel. Untuk lebih jelas dapat dilihat pada Tabel 11. 
Tabel 11. Varian Pengeluaran BOP Variabel Tahun 1996-2005

\begin{tabular}{cccc}
\hline Tahun & BOP Variabel Aktual (Rp) & Tarif BOP Var x Jam Aktual (Rp) & Varian (Rp) \\
\hline 1996 & $756.355 .382,00$ & $793.333 .313,50$ & $(36.977 .931,50) \mathrm{F}$ \\
1997 & $778.945 .856,00$ & $789.341 .686,65$ & $(10.395 .830,65) \mathrm{F}$ \\
1998 & $781.547 .892,00$ & $813.777 .480,03$ & $(32.229 .588,03) \mathrm{F}$ \\
1999 & $786.478 .592,00$ & $819.863 .353,33$ & $(33.384 .761,33) \mathrm{F}$ \\
2000 & $788.125 .487,00$ & $823.625 .000,00$ & $(35.499 .513,00) \mathrm{F}$ \\
2001 & $842.548 .789,00$ & $929.225 .000,00$ & $(86.676 .211,00) \mathrm{F}$ \\
2002 & $933.125 .874,00$ & $1.149 .041 .686,65$ & $(215.915 .812,65) \mathrm{F}$ \\
2003 & $941.547 .123,00$ & $1.298 .916 .686,65$ & $(357.369 .563,65) \mathrm{F}$ \\
2004 & $992.458 .125,00$ & $1.500 .250 .000,00$ & $(507.791 .875,00) \mathrm{F}$ \\
2005 & $1.245 .124 .892,00$ & $1.700 .283 .313,00$ & $(455.158 .421,00) \mathrm{F}$ \\
\hline Total & $8.846 .258 .012,00$ & $10.617 .657 .519,81$ & $(1.771 .399 .507,81) \mathrm{F}$ \\
Rata-rata & $884.625 .801,20$ & $1.061 .765 .751,98$ & $(177.139 .950,78) \mathrm{F}$ \\
\hline Sumber : Hasil Olahan Data Sekunder Tahun 2006 & &
\end{tabular}

Berdasarkan Tabel 11 diatas, varian rata-rata BOP variabel sebesar Rp $(177.139 .950,78)$

Favourable, dalam arti manajemen PT. BAM telah mampu menafsirkan biaya overhead variabel secara baik.

\section{Varian Efisiensi Overhead Variabel}

Varian efisiensi overhead variabel adalah varian antara tarif overhead variabel dikalikan jam aktual dengan tarif overhead variabel dikalikan jam standar. Berdasarkan jam aktual dan standar maka varian efisiensi overhead variabel dapat dicari dan dapat dilihat pada Tabel 12.

Tabel 12. Varian Efisiensi Overhead Variabel Pada PT. BAM

\begin{tabular}{cccc}
\hline Tahun & $\begin{array}{c}\text { Tarif O.V x Jam Aktual } \\
(\mathrm{Rp})\end{array}$ & $\begin{array}{c}\text { Tarif O.V x Jam Standar } \\
(\mathrm{Rp})\end{array}$ & Varian (Rp) \\
\hline 1996 & $793.333 .313,50$ & $799.999 .980,00$ & $(6.666 .666,50) \mathrm{F}$ \\
1997 & $789.341 .686,65$ & $790.000 .020,00$ & $(658.333,35) \mathrm{F}$ \\
1998 & $813.777 .480,03$ & $814.999 .980,00$ & $(1.222 .499,97) \mathrm{F}$ \\
1999 & $819.863 .353,33$ & $820.000 .020,00$ & $(136.666,67) \mathrm{F}$ \\
2000 & $823.625 .000,00$ & $825.000 .000,00$ & $(1.375 .000,00) \mathrm{F}$ \\
2001 & $929.225 .000,00$ & $930.000 .000,00$ & $(775.000,00) \mathrm{F}$ \\
2002 & $1.149 .041 .686,65$ & $1.150 .000 .020,00$ & $(958.333,35) \mathrm{F}$ \\
2003 & $1.298 .916 .686,65$ & $1.300 .000 .020,00$ & $(1.083 .333,35) \mathrm{F}$ \\
2004 & $1.500 .250 .000,00$ & $1.500 .000 .000,00$ & $250.000,00 \mathrm{~F}$ \\
2005 & $1.700 .283 .313,00$ & $1.699 .999 .980,00$ & $283.333,00 \mathrm{UF}$ \\
\hline Total & $10.617 .657 .519,81$ & $10.630 .000 .020,00$ & $(12.342 .500,19) \mathrm{F}$ \\
Rata-rata & $1.061 .765 .751,98$ & $1.063 .000 .002,00$ & $(1.234 .250,02) \mathrm{F}$ \\
\hline
\end{tabular}

Sumber : Hasil Olahan Data Sekunder Tahun 2006

Berdasarkan Tabel 12, varian rata-rata efisiensi overhead variabel sebesar Rp $(1.234 .250,02)$ favourable, dalam arti manajemen PT. BAM telah mampu menggunakan overhead secara efisien. 


\section{Total Varian Overhead Variabel}

Total varian overhead variabel adalah varian antara overhead variabel aktual dengan tarif overhead variabel dikalikan jam standar. Berdasarkan Tabel 13 dapat dihitung variannya. Untuk lebih jelas dapat dilihat pada Tabel

Tabel 13. Total Varian Overhead Variabel

\begin{tabular}{cccc}
\hline Tahun & $\begin{array}{c}\text { Overhead Variabel } \\
\text { Aktual (Rp) }\end{array}$ & $\begin{array}{c}\text { Tarif BOP Var x Jam } \\
\text { Standar (Rp) }\end{array}$ & Varian (Rp) \\
\hline 1996 & $756.355 .382,00$ & $799.999 .980,00$ & $(30.311 .265,00) \mathrm{F}$ \\
1997 & $778.945 .856,00$ & $790.000 .020,00$ & $(9.737 .497,30) \mathrm{F}$ \\
1998 & $781.547 .892,00$ & $814.999 .980,00$ & $(31.007 .088,06) \mathrm{F}$ \\
1999 & $786.478 .592,00$ & $820.000 .020,00$ & $(33.248 .094,66) \mathrm{F}$ \\
2000 & $788.125 .487,00$ & $825.000 .000,00$ & $(34.124 .513,00) \mathrm{F}$ \\
2001 & $842.548 .789,00$ & $930.000 .000,00$ & $(85.901 .211,00) \mathrm{F}$ \\
2002 & $933.125 .874,00$ & $1.150 .000 .020,00$ & $(214.957 .479,30) \mathrm{F}$ \\
2003 & $941.547 .123,00$ & $1.300 .000 .000,00$ & $(356.286 .230,30) \mathrm{F}$ \\
2004 & $992.458 .125,00$ & $1.500 .000 .000,00$ & $(507.041 .875,00) \mathrm{F}$ \\
2005 & $1.245 .124 .892,00$ & $1.699 .999 .980,00$ & $(455.441 .754,00) \mathrm{F}$ \\
\hline Total & $8.846 .258 .012,00$ & 10.630 .000 .020 & $(1.759 .057 .007,62) \mathrm{F}$ \\
Rata-rata & $884.625 .801,20$ & $1.063 .000 .002,00$ & $(175.905 .700,76) \mathrm{F}$ \\
\hline
\end{tabular}

Sumber : Hasil Olahan Data Sekunder Tahun 2006

Berdasarkan tabel diatas, varian rata-rata overhead variabel sebasar $\operatorname{Rp}(175.905 .700,76)$ favourable, dalam arti manajemen PT. BAM telah mampu menafsirkan dan menggunakan overhead secara baik dan efisien. Overhead Pabrik Tetap Varian Pengeluaran Overhead Tetap pengeluaran overhead tetap adalah varian antara overhead tetap aktual dengan overhead tetap yang dianggarkan.

Tabel 14. Varian Pengeluaran Overhead Tetap Pada PT. BAM

\begin{tabular}{cccc}
\hline Tahun & $\begin{array}{c}\text { Overhead Tetap Aktual } \\
(\mathrm{Rp})\end{array}$ & $\begin{array}{c}\text { Anggaran Overhead Tetap } \\
(\mathrm{Rp})\end{array}$ & Varian $(\mathrm{Rp})$ \\
\hline 1996 & $456.146 .077,00$ & $610.300 .000,00$ & $(154.153 .923,00) \mathrm{F}$ \\
1997 & $358.022 .217,00$ & $590.300 .000,00$ & $(232.277 .783,00) \mathrm{F}$ \\
1998 & $634.690 .461,00$ & $648.926 .000,00$ & $(14.235 .539,00) \mathrm{F}$ \\
1999 & $801.348 .704,00$ & $855.128 .360,00$ & $(53.779 .656,00) \mathrm{F}$ \\
2000 & $988.870 .723,00$ & $989.145 .386,00$ & $(274.663,00) \mathrm{F}$ \\
2001 & $1.050 .000 .000,00$ & $1.150 .000 .000,00$ & $(100.000 .000,00) \mathrm{F}$ \\
2002 & $1.115 .000 .000,00$ & $1.210 .000 .000,00$ & $(95.000 .000,00) \mathrm{F}$ \\
2003 & $1.250 .000 .000,00$ & $1.400 .000 .000,00$ & $(150.000 .000,00) \mathrm{F}$ \\
2004 & $1.365 .800 .420,00$ & $1.580 .000 .000,00$ & $(214.199 .580,00) \mathrm{F}$ \\
2005 & $1.844 .558 .752,02$ & $1.850 .308 .313,33$ & $(5.749 .561,31) \mathrm{F}$ \\
\hline Total & $9.595 .223 .602,00$ & $10.883 .799 .746,00$ & $(1.019 .670 .705,31) \mathrm{F}$ \\
Rata-rata & $959.522 .360,20$ & $1.083 .379 .974,60$ & $(101.967 .070,53) \mathrm{F}$ \\
\hline
\end{tabular}

Sumber : Hasil Olahan Data Sekunder Tahun 2006 
Varian rata-rata pengeluaran overhead tetap sebesar $\mathrm{Rp}(101.967 .070,53)$ favourable, dalam arti manajemen PT. BAM telah menggunakan overhead secara baik dan efisien.

\section{Varian Volume Overhead Tetap}

Varian volume overhead tetap adalah varian antara overhead tetap dianggarkan dengan overhead tetap dibebankan dimana variannya dapat dilihat pada Tabel 15.

Tabel 15. Varian Volume Overhead Tetap

\begin{tabular}{cccc}
\hline Tahun & Anggaran O.T (Rp) & Overhead Tetap Yg dibebankan (Rp) & Varian (Rp) \\
\hline 1996 & $610.300 .000,00$ & $604.916 .686,50$ & $5.383 .313,50 \mathrm{UF}$ \\
1997 & $590.000 .000,00$ & $599.500 .000,00$ & $(9.200 .000,00) \mathrm{F}$ \\
1998 & $648.926 .000,00$ & $649.024 .980,03$ & $(98.980,03) \mathrm{F}$ \\
1999 & $855.128 .360,00$ & $859.856 .646,67$ & $(4.728 .286,67) \mathrm{F}$ \\
2000 & $989.145 .386,00$ & $998.333 .353,30$ & $(9.187 .967,30) \mathrm{F}$ \\
2001 & $1.150 .000 .000,00$ & $1.199 .000 .000,00$ & $(49.000 .000,00) \mathrm{F}$ \\
2002 & $1.210 .000 .000,00$ & $1.248 .958 .313,35$ & $(38.958 .313,35) \mathrm{F}$ \\
2003 & $1.400 .000 .000,00$ & $1.498 .750 .000,00$ & $(98.750 .000,00) \mathrm{F}$ \\
2004 & $1.580 .000 .000,00$ & $1.600 .000 .020,00$ & $(20.000 .020,00) \mathrm{F}$ \\
2005 & $1.850 .000 .000,00$ & $1.850 .308 .313,33$ & $(308.313,33) \mathrm{F}$ \\
\hline Total & $10.833 .799 .746,00$ & $11.058 .639 .999,85$ & $(224.848 .567,18) \mathrm{F}$ \\
Rata-rata & $1.083 .379 .974,60$ & $1.105 .863 .999,99$ & $(22.484 .856,72) \mathrm{F}$ \\
\hline
\end{tabular}

Varian rata-rata volume overhead tetap sebesar $\operatorname{Rp}(22.484 .856,72)$ favourable, dimanai manajemen PT. BAM telah mampu mengukur keluaran aktual dengan keluaran yang digunakan dengan baik.

\section{Total Varian Overhead Tetap}

Total varian overhead tetap adalah varian antara overhead tetap aktual dengan overhead tetap yang dibebankan, dimana variannya dapat dilihat pada Tabel 16.

Tabel 16. Total Varian Overhead Tetap

\begin{tabular}{cccc}
\hline Tahun & Overhead Tetap Aktual (Rp) & O.T Yg Dibebankan (Rp) & Varian (Rp) \\
\hline 1996 & $456.146 .077,00$ & $604.916 .686,50$ & $(159.537 .236,50) \mathrm{F}$ \\
1997 & $358.022 .217,00$ & $599.500 .000,00$ & $(223.077 .783,00) \mathrm{F}$ \\
1998 & $634.690 .461,00$ & $649.024 .980,03$ & $35.665 .480,97 \mathrm{UF}$ \\
1999 & $801.348 .704,00$ & $859.856 .646,67$ & $(58.507 .942,67) \mathrm{F}$ \\
2000 & $988.870 .723,00$ & $998.333 .353,30$ & $(9.462 .630,30) \mathrm{F}$ \\
2001 & $1.050 .000 .000,00$ & $1.199 .000 .000,00$ & $(149.000 .000,00) \mathrm{F}$ \\
2002 & $1.115 .000 .000,00$ & $1.248 .958 .313,35$ & $(133.958 .313,35) \mathrm{F}$ \\
2003 & $1.250 .000 .000,00$ & $1.498 .750 .000,00$ & $(248.750 .000,00) \mathrm{F}$ \\
2004 & $1.365 .800 .420,00$ & $1600.000 .020,00$ & $(234.199 .600,00) \mathrm{F}$ \\
2005 & $1.844 .558 .752,02$ & $1.850 .308 .313,33$ & $(5.441 .561,31) \mathrm{F}$ \\
\hline Total & $9.595 .223 .602,00$ & $11.058 .639 .999,85$ & $(1.18 .626 .927,28) \mathrm{F}$ \\
Rata-rata & $959.522 .360,20$ & $1.105 .863 .999,99$ & $(118.626 .927,28) \mathrm{F}$ \\
\hline
\end{tabular}

Sumber : Hasil Olahan Data Sekunder Tahun 2006 
Berdasarkan tabel diatas, varian rata-rata overhead tetap sebesar $\operatorname{Rp}(118.626 .927,28)$ favourable, dalam arti manajemen PT. BAM telah mampu menafsirkan dan menggunakan overhead secara baik dan efisien.Pengendalian adalah proses untuk menjamin tercapainya rencana yang telah ditetapkan. Sistem pengendalian berusaha memonitor pelaksanaan dalam mencapai tujuan yang spesifik yang telah ditentukan sebelumnya.Suatu usaha untuk menjamin penggunaan sumber-sumber biaya secara efisien dan efektif umumnya digunakan evaluasi pelaksanaan atau prestasi kerja berdasarkan standar yang telah ditetapkan. Biaya standar dapat dipakai sebagai alat pengendalian biaya dalam menilai keberhasilan pelaksanaan penggunaan biaya.Dengan membandingkan biaya aktual yang terjadi dan biaya standar yang telah ditetapkan sebelumnya, maka diketahui besarnya varian biaya produksi yang terjadi.

Tabel 17. Varian Biaya Produksi Tahun 1996-2005

\begin{tabular}{llll}
\hline Tahun & $\begin{array}{l}\text { Biaya Produksi Aktual } \\
(\mathrm{Rp})\end{array}$ & $\begin{array}{l}\text { Biaya Produksi Standar } \\
(\mathrm{Rp})\end{array}$ & Varian (Rp) \\
\hline 1996 & $24.776 .329 .909,00$ & $35.650 .112 .048,75$ & $(10.873 .782 .139,75) \mathrm{F}$ \\
1997 & $16.998 .384 .273,00$ & $33.569 .665 .444,05$ & $(16.571 .281 .171,05) \mathrm{F}$ \\
1998 & $31.296 .954 .383,00$ & $40.689 .356 .108,53$ & $(9.392 .401 .725,53) \mathrm{F}$ \\
1999 & $43.807 .167 .896,00$ & $63.715 .788 .274,23$ & $(19.908 .620 .378,23) \mathrm{F}$ \\
2000 & $54.255 .513 .210,00$ & $71.040 .117 .031,13$ & $(16.784 .603 .821,12) \mathrm{F}$ \\
2001 & $64.222 .569 .039,00$ & $81.486 .042 .657,42$ & $(17.263 .473 .618,42) \mathrm{F}$ \\
2002 & $62.223 .791 .374,00$ & $96.933 .933 .581,33$ & $(34.710 .142 .207,33) \mathrm{F}$ \\
2003 & $74.003 .684 .873,00$ & $106.081 .724 .973,93$ & $(32.078 .040 .100,93) \mathrm{F}$ \\
2004 & $86.281 .752 .395,00$ & $186.122 .215 .929,50$ & $(99.840 .463 .534,50) \mathrm{F}$ \\
2005 & $104.109 .434 .344,02$ & $214.946 .144 .273,61$ & $(110.836 .709 .929,59) \mathrm{F}$ \\
\hline Total & $561.706 .367 .944,00$ & $930.185 .092 .009,14$ & $(368.259 .518 .626,45) \mathrm{F}$ \\
Rata-rata & $56.170 .636 .794,40$ & $93.018 .509 .200,91$ & $(36.825 .951 .862,65) \mathrm{F}$ \\
\hline Sumber : Hasil Olahan Data Sekunder TaShun 2006 &
\end{tabular}

Rata-rata varian biaya produksi bersifat favourable dengan nilai sebesar Rp $(36.825 .951 .862,65)$, dalam arti manajemen puncak telah merencanakan standar biaya produksi dengan efektif. Berdasarkan varian biaya produksi yang terjadi maka dapat dilakukan tindakan koreksi oleh pihak perusahaan. Apabila varian biaya produksi yang terjadi unfavourable (merugikan), maka standar tersebut harus direvisi atau diubah menjadi standar yang baru.PT. BAM dalam perbaikan atau perubahan standar dilakuakn pada akhir periode akuntansi. Meskipun standar yang telah ditetapkan telah mengalami kekeliruan, perbaikan standar harus ditunda sampai berakhirnya periode akuntansi. Keputusan ini dilakukan oleh perusahaan, karena jika standar diperbaiki dalam periode, perubahan tersebut akan menghancurkan standar sebagai alat pengukur yang efisien.Berdasarkan hasil wawancara dengan pihak perusahaan, pada biaya produksi yang tetap PT. BAM (Biaya standar) akan dilakukan perubahan secara menyeluruh 
apabila varian biaya standar dengan biaya aktual terjadi unfavourable $>30 \%$ terhadap biaya standar. Sedangkan apabila terjadi selisih unfavourable $<30 \%$ terhadap standar, maka PT. BAM akan melakuakan peninjauan kembali atau melakukan beberapa revisis terhadap biaya standar yang akan ditetapkan.

\section{KESIMPULAN DAN SARAN}

\section{Kesimpulan}

Berdasarkan hasil penelitian dari analisa data, maka dapat ditarik kesimpulan sebagai berikut :

1. Nilai biaya tetap yang terjadi pada PT. Bukit Angkasa Makmur pada tahun 2005 sebesar Rp 8.063.423.856,10 dan nilai biaya variabelnya sebesar Rp 221.881.029.070,92.

2. Usaha pengolahan karet Crumb Rubber PT. Bukit Angkasa Makmur telah mencapai tingkat pengolahan minimum bahkan telah mendapat keuntungan. Titik impas (dalam rupiah) pada PT. BAM sebesar Rp 201.585.596.402,50 dan titik impas (dalam unit) sebesar 21.894.818,77 Kg.

3. Nilai Margin Kontribusi dari volume penjualan total karet yang dilakukan PT. Bukit Angkasa Makmur adalah sebesar Rp 8.339.796.622,00 dan Nilai Rasio Margin Kontribusi sebesar 0,04

4. Varian favourable dan varian unfavourable dalam proses produksi pada PT. BAM adalah :

a. Hasil perhitungan rata-rata varian bahan baku mengalami varian favourable senilai $R p$ $(36.507 .552 .431,49)$. Artinya bahwa bagian pembelian telah mampu merencanakan biaya standar bahan baku dengan baik.

b. Hasil perhitungan rata-rata varian tenaga kerja langsung mengalami varian favourable senilai Rp (49.296,00). Artinya pihak manajemen PT. BAM telah mampu menetapkan tarif standar yang sesuai dengan jenis pekerjaan dan keterampilan yang dimiliki tenaga kerja.

c. Hasil perhitungan rata-rata Svarian overhead

d. variabel mengalami varian favourable senilai $\mathrm{Rp}(175.905 .700,76)$. Artinya pihak manajemen PT. BAM telah mampu menafsirkan dan menggunakan overhead secara baik dan efisien. 
e. Hasil perhitungan rata-rata varian overhead tetap mengalami varian favourable senilai Rp $(118.626 .927,28)$. Artinya pihak manajemen PT. BAM telah mampu menafsirkan dan menggunakan overhead secara baik dan efisien.

f. Hasil perhitungan rata-rata varian biaya produksi pada PT. BAM senilai $(36.825 .951 .862,65)$ favourable. Artinya manajemen puncak telah merencanakan standar biaya produksi dengan baik.

\section{Saran}

1. Perusahaan diharapkan mampu memanfaatkan biaya yang ada dengan sebaik-baiknya untuk memenuhi kebutuhan produksi.

2. Perusahaan telah mencapai tingkat pengolahan minimum, maka diharapkan kedepan perusahaan mampu mempertahankannya, dengan meningkatkan produksi yang sesuai dengan keinginan pembeli.

3. Sejalan dengan meningkatnya pengolahan minimum, diharapkan perusahaan dapat meningkatkan nilai margin kontribusi rasio marjin kontribusi sehingga dapat menutupi biaya tetap pada periode itu.

4. Pihak manajemen diharapkan mampu mempertahankan dan meningkatkan kinerjanya dalam menafsirkan biaya produksi yang akan terjadi.

\section{DAFTAR PUSTAKA}

Ahmad. 1997. Akuntansi Manajemen. Dasar-dasar Konsep Biaya dan Pengambilan Keputusan. PT. Raja Grafindo Persada. Jakarta.

Akhmad Darajat Asep. Skripsi. 2000. Analisis Titik Impas, Kemampuan Memperoleh Laba dan Peramalan Penjualan Pada Usaha Tambak. Universitas Bengkulu.

Adi Saputra, Gunawan. 1998. Anggaran Perusahaan 2. Yogyakarta. BPFE. Universitas Gajah Mada.

A. Chasin. 1986. Akuntansi Biaya, Perencanaan dan Pengendalian. Erlangga. Malang.

Arsyad. 1993. Analisis Break Even Point. BPFE. UGM. Yogyakarta.

Arafat, Yasir,2004. Analisa Kinerja Keuangan Dalam Usaha Meningkatkan Laba CV. Mitra Usaha Palembang. Jurnal Media Wahana Ekonomika, Vol 1 No 1.

Adelina, Sjahrum dan Panjaitan. 1986. Peramalan Produksi Tanaman Kelapa sawit Di Kebun Bukit Sentang. Buletin Perkebunan.

Dinora, A. 1998. Skripsi. Analisis Break Even Point Dalam Perencanaan Laba Pada Perusahaan Daerah Air Minum Kotamadya Payakumbuh. Fakultas Ekonomi. UNAND. Padang.

Edilus dan Sudarsono. 1994. Kamus Ekonomi Uang dan Bank. Rineka Cipta. Jakarta.

Ferry. 1993. Tekhnik Merencanakan Laba. PPm. Erlangga. Jakarta. 
Garrison, HR. 1997. Akuntansi Manajemen, Konsep, Untuk Perencanaan, Pengendalian dan

Pengambilan Keputusan (Terjemahan). ITB. Bandung.

Limbong dan Sitorus. 1987. Pengantar Tataniaga Pertanian. IPB. Bogor.

Mulyadi. 1990. Analisis Manajemen Keuangan. Yogyakarta. BPFE. UGM. Yogyakarta..

Mulyadi. 1993. Akuntansi Manajemen, Konsep dan Perencanaan. STIE. YKPN. Yogyakarta.

Munawir. 1992. Analisis Laporan Keuangan. Yogyakarta. UGM. Liberty.

Matz dan Usry. 1990. Akuntansi Biaya, Perencanaan dan Pengendalian. Erlangga. Jakarta.

Mas'ud. 1996. Akuntansi Manajemen, Perencanaan dan Pembuatan Keputusan Jangka Pendek.

Mulyadi dan Setyawan, J. 1999. Sistem Perencanaan dan Pengendalian Manajemen (Sistem Pelipatgandaan Kinerja Perusahaan). Aditya Media. Yogyakarta.

Nusril, 1999. Analisis CVP Untuk Perencanaan Laba dan Pertumbuhan Usaha Tambak Udang Semi-Intensif. Desiminasi Hasil Penelitian Lembaga Penelitian UNIB. Volume 02 Tahun 1998/1999.

Riyanto, Bambang. 1995. Dasar-dasar Pembelanjaan Perusahaan. Yayasan Penerbit Gajah Mada. Yogyakarta.

Supriyono. 1987. Akuntansi biaya, Pengumpulan Biaya dan Penentuan Harga Pokok. BPFE. Yogyakarta.

Sigit, Soehardo. 1991. Analisis Break Even Point. BPFE. UGM. Yogyakarta.

Siahaan, Nelson Dapot. Skripsi. 2002. Analisa Titik Impas Sebagai Dasar Perencanaan Laba Pada Perusahaan Tahu (Kasus Pada Perusahaan Tahu Sumber Mulya Dan Sadono). Jurusan Sosial Ekonomi. Fakultas Pertanian. UNIB. Bengkulu(tidak dipublikasikan).

Swata Basu, DH dan Irawan. 1993. Manajemen Perusahaan. Yogyakarta. Liberti.

Sofyan Assauri. 1993. Manajemen Produksi dan Operai. IPFE-UI. Jakarta. 